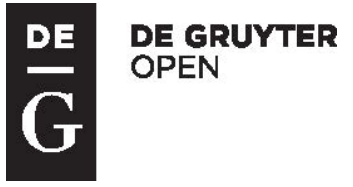

\title{
Letter from the Issue Editor
}

Joining the numerous and varied events worldwide that marked the 400 years from the death of William Shakespeare, the English Department of the "Alexandru Ioan Cuza" University of Iaşi organized a conference entitled $R e$ Reading, Re-Writing, Re-Contextualizing Shakespeare, conceived as a celebration of Shakespeare's afterlife. This collection of papers is the result of the conference presentations and discussion and can be seen as a journey through the various manners in which Shakespeare's work has been re-read, rewritten and re-contextualized for the past 400 years. The articles offer new and challenging readings of the Shakespearean text from various vantage points: performance and critical studies; attempts to re-contextualize the plays either in the light of recent discoveries or against the background of early-modern scientific, philosophical or cultural texts; translation, re-writing and adaptation through various media. Or, in other words, they display the varied ways in which generations of critics, teachers and students, directors and actors, film-makers, musicians and artists, performers and audiences have "seen" Shakespeare's works, with all the complex meanings that this verb carries.

The first article explores the different meanings of the verb "to see" in Shakespeare's plays by starting from the belief that critics and academics have tended to ignore the performance part of Shakespeare's work in favour of the critical approaches, often forgetting that the Bard wrote for the stage and not for the page and that performance studies may reveal more about a play's nuances than critical reading. This argument is developed by Michael Hattaway in his article Re-Shaping "King Lear": Space, Place, Costume and Genre. Unlike critical approaches, performance is a form of re-creation and adaptation, it is never fixed and it can generate more readings of the same play. By using the word "denotement", Shakespeare draws the audiences into "seeing" more, not with the body's eye, but with the mind's eye, into reading, interpreting, contextualising what they see and using their imagination as a creative process of story-telling in order to have access not only to what characters do on stage, but how they feel and what they think beyond words and gestures.

Monica Matei-Chesnoiu's article The Eye and Refractive Geography in "Pericles" is also connected to "seeing", but from a different perspective, that of the "cultural constructedness of vision in the early modern period" (p. 35) from the treatises on anatomy and physiology to poetry, philosophy, geometry, etc. The special reference to Pericles is due to the fact that the imagination of the 
audiences is forced to stretch and cover vast expanses of land. Monica MateiChesnoiu argues that "the imaginative spatial conventions of the play can be assimilated to the system of geometrical projection on which maps depended" (p. 35) suggesting that the early modern playwrights were drawn not only by the conventions inherited from the classical authors, but also to the contemporary developments in the arts and sciences to compensate for the bareness of the stage with "ubiquity of action over a large geographic expanse" (p. 48).

Modern discoveries may also lead to new interpretations of Shakespeare's famous plays, as is the case with Siobhan Keenan's Re-Reading Shakespeare's "Richard III": Tragic Hero and Villain ? In the light of the discovery of King Richard III's body in Leicester and of the renewed interest in the re-evaluation of the true historical role of this long-vilified king, Siobhan Keenan proposes a different outlook on one of Shakespeare's most famous characters, Richard III. Represented as a demon in Tudor mythology, Richard has epitomized villainy, cold-blooded cruelty and deceit. Shakespeare's role in perpetuating this negative representation is very important, as the image of Richard in the popular imagination has not been shaped by historical writings, but mostly by Shakespeare's famous play. Nevertheless, though Shakespeare seemed to remain within the lines of the Tudor ideology, his real intentions are more difficult to read, and, as Siobhan Keenan aptly demonstrates in the paper, Richard's character is not only more appealing and charismatic than expected, but also more complicated and nuanced. By closely analysing some key passages in the play, Siobhan Keenan suggests that Richard draws closer to Shakespeare's later tragic heroes, flawed, but possessing charisma and a tragic stature in front of the inevitable fall.

The changes in historical or cultural perspectives that influence the manner in which we now understand and connect to older texts are also clear in Gary Harrington's article "Shadowed Livery": Morocco in "The Merchant of Venice". Though traditionally considered an anti-Semitic play, The Merchant of Venice actually seems to tell a different story. Thus, without focusing only on the famous Shylock, as most analyses do, but also on other characters, mostly the marginal Prince of Morocco, Gary Harrington argues that Shakespeare is far from being a racist. On the contrary, after carefully reading the nuances, Shakespeare emerges as a promoter of diversity, of gender, racial and religious variety that gives a society dynamism and verve and provides a meaningful counterpoint to sterile uniformity and conformity.

Adaptation, translation and re-writing are very common forms through which Shakespeare's works have "lived" during these 400 years, but we often forget that Shakespeare himself was an adapter of older and, often, very famous sources. This special topic is the focal point of Codrin Liviu Cuțitaru's article entitled The Genius of Shakespeare's Plagiarisms. Case Studies: "Hamlet", "Othello", "King Lear" and "Macbeth". Re-writing and adapting various 
already existing texts for the stage was a common practice in the Renaissance theatre, however, as Codrin Liviu Cuțitaru argues, Shakespeare does more than simply reproducing and adapting a story for the stage. He introduces nuances that did not exist in the original texts. Thus, the article focuses on one of the most important aspects of Shakespeare's adaptations, namely the "cultural conflict", present in all his major tragedies whose heroes "are, at their profoundest levels of consciousness, the prisoners of a psychological antagonism with cultural connotations (basically related to identity and mentality issues)" (p. 64).

Alan Forrest Hickman's paper "Subject to Invent": Adaptation of Shakespeare's Sonnets into Other Media follows the afterlife of Shakespeare's sonnets. Though apparently surpassed by the plays in public success, the Sonnets have still been subjected to reinterpretation, used and adapted, from political speeches and wedding vows to music, television and film. Alan Hickman's article tackles the adaptation of the Sonnets into various media, especially books, television and movies, suggesting that they are part of an undergoing process of remediation (p. 92) that may help larger audiences connect to these rather difficult texts by Shakespeare and, why not, to his biography.

Working still along the lines of adaptation, Nicoleta-Mariana Iftimie's article, The Role of Media in Baz Luhrmann's "Romeo+Juliet", investigates the role of television and printed media in one of the most famous films of an equally famous Shakespearean play. Introduced and concluded by the image of a television set, the famous story of the "star-crossed" lovers seems to enter our houses in the form of a television programme. Thus, the director and co-writer Baz Luhrmann adapted the Renaissance play into a modern story in which the information is broadcast via television or printed media, the characters themselves find out the latest news from the TV or appear on the cover of magazines. The tragedy is framed by the TV or magazine in a way that is similar to the way in which we, participants in the modern world, find out about the happy or distressing events in other "ordinary" people's lives. Thus, the love between Romeo and Juliet or the brawl between the two families aggressively penetrate our daily existence and question the apparent tranquillity in which we believe we lead our lives.

Agnieszka Romanowska's "I Hate You, Romeo". A Heretic Re-Writing of "Romeo and Juliet" is another adaptation of the story of the two emblematic lovers. It dwells on the play written by the Polish writer Jarosław Iwaszkiewicz. By discussing the circumstances lying at the basis of this radical reinterpretation of the famous Shakespearean play, with a focus on Iwaszkiewicz's personal existence as well as on his pessimistic views on life and love as expressed in his literary pieces, Agnieszka Romanowska, in fact, unveils the complicated process of adaptation and re-writing. Thus, it becomes clear that the relationship between the original text and the author who chooses to adapt and re-write it is a very 
complex adventure that is affected by various factors beyond the literary ones, ranging from socio-cultural conditions to emotional or psychological aspects.

Laurence Raw's tribute to George Wilson Knight, one of the greatest and most influential Shakespearean critics aptly concludes this issue by reaching out, through Wilson Knight, to all those who, during these four centuries, have loved Shakespeare and written about him. The choice of Wilson Knight is important especially in our world that seems to gradually succumb to technology, loss of identity and impersonality. Starting from a love of Shakespeare kindled by the stage productions he saw as a child, G. Wilson Knight grew into a refined critic who combined the critical insight with a Christian outlook on existence. Thus, he believed that "poetic creation evolves naturally out of a union between 'earth' and 'heaven,' the material and the spiritual" (p. 111). Grounded on a thorough knowledge of literature and of the texts he approached, Wilson Knight seemed to favour the "mesearch-related interpretive activities where personal feelings matter more than scholarly apparatus" (p. 121).

"Our revels now are ended", says Prospero, in The Tempest (5.1), whereas Puck promises to repair what we consider wrong: "If we shadows have offended, / Think but this, and all is mended, / That you have but slumber'd here /While these visions did appear" (A Midsummer Night's Dream, Epilogue). This is how Shakespeare saw his own works, as "visions" or dreams subjected to transformation and "mending". And let us not forget that the Latin source of the word "vision" is "Visio", an "act of seeing, sight, things seen," (www.etymonline.com). In this light, we can also see our collection of articles as one of the countless tributes to Shakespeare, in these 400 years of uninterrupred critical reception, offering new perspectives from which to see his works, with our mind, and, why not, with our heart. 